\title{
Controversy in the Management of Congenital Cornea Opacification
}

\author{
James V Aquavella* \\ University of Rochester Flaum Eye Institute, USA
}

Submission: December 13, 2017; Published: January 03, 2018

*Corresponding author: James V Aquavella, University of Rochester Flaum Eye Institute, 601 Elmwood Ave., Box 659, Rochester, NY 14642, USA,

Tel: 585-275-8944; Email: James_Aquavella@urmc.rochester.edu

\section{Short Communication}

The management challenges associated with congenital ocular disease in infants have long been recognized. Depending on the degree of microphthalmos, vascularized cornea opacity, iris and lens dysgenesis, buphthalmous, and glaucoma many of these infants have been declared to be irreversibly blind.

Penetrating keratoplasty has been attempted in some milder cases where the pathology is limited to the cornea in an effort to avoid subsequent amblyopia but pediatric corneal transplants are associated with a high risk of graft failure and complications $[1,2]$. In the more severe cases standard cornea transplantation is contraindicated.

In the adult population, since the introduction of the Boston I device, keratoprosthesis is being increasingly utilized as an important alternative to cornea transplantation as well as the newer endothelial replacement techniques. Infants however constitute a significantly different category with anatomic and biological systems evolving, active immune response, and the absence of a clear understanding of the underlying diagnosis [3].

The recent publication of a small series of pediatric keratoprosthesis procedures performed by a single surgeon under standard conditions highlighted serious and irreversible complications with the authors' conclusion that the procedure should not be performed [4].

Yet one group has reported a level of visual restoration utilizing a combination of multidisciplinary approach, specialized surgical techniques, intense preoperative evaluation and a comprehensive postoperative management style [5-7]. While we await their long term results, it is clear that a useful level of acuity can be preserved in some cases. In view of these diverse opinions the question has been raised: should this work continue?

It is clear that the provision of some level of vision, even if transient, is associated with a significant positive impact on infant development. The Texas School for the Blind and Visually Impaired has categorized these beneficial effects in areas of sensory development, motor development, selfconcept, cognitive development, social development, language development, and experience [8].

The early visual experience in newborn infants has been studied and shown to have an important role in the development of spatial cognition [9]. Severe visual impairment however has a profound negative effect on the development of bilateral coordination. And childhood blindness can be said to have a negative effect on growth, development, social and economic opportunities [10].

What then are the negatives? Since these cases are rare and the techniques specialized families must travel long distances to centers where care is available, cases must be screened for the parents ability to maintain years of frequent examinations (many under anesthesia), they must have the means of providing the intense postoperative management. Drops must be instilled frequently at first but some are necessary for life, local eye physicians must be available for consultation, and a variety of potential complications must be avoided, or if present recognized and treated.

Should the children of parents committed to providing this necessary intensive care be denied not only the potential for useful vision but the positive effects on development as well? Should we not expect that over time those pioneers who provide care to this population will become more proficient and that new discoveries and improvements will result in a reduction of complications as well as an increase in the number of providers willing to participate?

With advances in medicine and science we anticipate that a larger percentage of these unfortunate cases will become amenable to improved visual restoration and preservation techniques based on advances in the currently available technology.

Thus in the final analysis, despite the recently reported experiences of our colleagues, and in view of our strong belief 
that significantly different preoperative, operative, and postoperative approaches do result in the provision of useful vision, the continued treatment of infants afflicted with severe congenital corneal opacity must continue.

\section{References}

1. Zaidman GW, Flanagan JK, Furey CC (2007) Long-term visual prognosis in children after corneal transplant surgery for peters anomaly type I. Am J Ophthalmol 144(1):104-108.

2. Karadag R, Chan TC, Azari AA, Nagra PK, Hammersmith KM, et al (2016) Survival of primary penetrating keratoplasty in children. Am J Ophthalmol 171: 95-100.

3. Nischal KK (2015) Genetics of congenital corneal Opacification. Cornea 34 Suppl 10: S24-S34.

4. Huang C, O’Hara M, Mannis MJ (2009) Primary pediatric keratoplasty: Indications and outcomes. Cornea 28(9): 1003-1008.

This work is licensed under Creative Commons Attribution 4.0 License

DOI: $10.19080 /$ JOJO.2018.06.555682
5. Aquavella, James V, Garrick Chak (2013) Infant Keratoprosthesis."Copeland and Afshari's Principles and Practice of Cornea. Chapter 91, Jaypee-Highlights Medical, New Delhi, India, 2: 1183-1193.

6. Aquavella JV, Gearinger MD, Akpek EK, McCormick GJ (2007) Pediatric Keratoprosthesis. Ophthalmol 114(5): 989-994.

7. Herzlich AA, Aquavella JV (2013) Infant keratoprosthesis. Int Ophthalmol Clin 53(2): 71-77.

8. Chris Strickling, Impact of Visual Impairment on Development. Texas School for the Blind and Visually Impaired, USA.

9. Pasqualotto A, Proulx MJ (2012) The role of visual experience for the neural basis of spatial cognition. Neurosci Biobehav Rev 36(4): 11791187.

10. Gognte P, Gilbert C, Zin A (2011) Childhood Blindness has an adverse effect on growth, development, social and economic opportunities. Middle East Afr J Ophthalmol 18(2): 109-114.

\begin{tabular}{|l|}
\hline \multicolumn{1}{|c|}{ Your next submission with Juniper Publishers } \\
will reach you the below assets \\
- Quality Editorial service \\
- Swift Peer Review \\
- Reprints availability \\
- E-prints Service \\
- Manuscript Podcast for convenient understanding \\
- Global attainment for your research \\
- Manuscript accessibility in different formats \\
( Pdf, E-pub, Full Text, Audio) \\
- Unceasing customer service \\
Track the below URL for one-step submission \\
https://juniperpublishers.com/online-submission.php \\
\hline
\end{tabular}

